\section{JURNAL EKONOMI EFEKTIF}

ISSN : $2622-8882$, E-ISSN : 2622-9935

Jurnal Ekonomi Efektif, Vol. 1, No. 4, Juli 2019

@Prodi Manajemen Fakultas Ekonomi Universitas

Pamulang

\title{
PENGARUH LINGKUNGAN KERJA TERHADAP KINERJA KARYAWAN PADA PT. INTI BOGA LESTARI DI JAKARTA SELATAN
}

\author{
Eti Ariyanti \\ Universitas Pamulang, Tangerang Selatan, Banten, Indonesia \\ *dosen02302@unpam.ac.id
}

\begin{abstract}
ABSTRAK
Penelitian ini bertujuan untuk mengetahui pengaruh lingkungan kerja terhadap kinerja karyawan pada PT. Inti Boga Lestari di Jakarta Selatan. Metode yang digunakan adalah explanatory research dengan sampel sebanyak 58 responden. Teknik analisis menggunakan analisis statistik dengan pengujian regresi, korelasi, determinasi dan uji hipotesis. Hasil penelitian ini variabel lingkungan kerja diperoleh nilai rata-rata skor sebesar 37,67 dengan kriteria baik. Variabel kinerja karyawan diperoleh nilai rata-rata skor sebesar 37,90 dengan kriteria baik. Lingkungan kerja berpengaruh positif dan signifikan terhadap kinerja karyawan dengan nilai persamaan regresi $\mathrm{Y}=10,647+0,723 \mathrm{X}$, dan nilai koefisien korelasi 0,795 atau memiliki tingkat hubungan yang kuat dengan nilai determinasi 63,3\%. Uji hipotesis diperoleh signifikansi $0,000<0,05$.
\end{abstract}

\section{Kata Kunci: Lingkungan Kerja, Kinerja Karyawan.}

\section{ABSTRACT}

This study aims to determine the effect of the work environment on employee performance at PT. Inti Boga Lestari in South Jakarta. The method used is explanatory research with a sample of 58 respondents. The analysis technique uses statistical analysis with regression testing, correlation, determination and hypothesis testing. The results of this study, the work environment variable obtained an average score of 37.67 with good criteria. Employee performance variables obtained an average score of 37.90 with good criteria. The work environment has a positive and significant effect on employee performance with the regression equation $Y=10.647+0.723 X$, and the correlation coefficient value of 0.795 or has a strong level of relationship with a determination value of $63.3 \%$. Hypothesis testing obtained a significance of $0.000<0.05$.

Keywords: Work Environment, Employee Performance. 


\section{PENDAHULUAN}

\section{A. Latar Belakang Masalah}

Perkembangan dunia saat ini semakin tinggi, sehingga perusahaan di dalam mengelola usaha diharapkan mampu menggunakan Sumber Daya Manusia (SDM) dengan baik dan benar. Setiap perusahaan mempunyai sasaran dan tujuan. Tujuan dari didirikannya perusahaan adalah untuk memperoleh laba atau keuntungan yang sebesar-besarnya. Untuk mencapai yang maksimal perusahaan mempunyai faktor-faktor produksi secara umum terdiri dari man(manusia), material(bahan), method(metode), machines(mesin), money(uang) and market(pasar) diantara faktor-faktor tersebut manusia mendapatkan perhatian khusus tanpa mengabaikan kelima faktor lainnya. Peranan manusia dalam perusahaan dapat dikatakan melebihi peranan yang dimiliki oleh faktor-faktor lainnya.

Manusia mempunyai batasan kemampuan dan tingkat kejenuhan tertentu. Lingkungan kerja yang kurang nyaman dan kondusif akan berdampak pada kinerja yang menurun dan tidak optimal. Maka dari itu lingkungan kerja merupakan faktor yang sangat mempengaruhi kinerja pada karyawan khususnya dan organisasi/perusahaan pada umumnya. Dalam cakupan yang lebih luas kedudukan SDM dalam suatu sistem yang lebih besar yaitu strategi organisasi. Dalam penempatan sasaran-sasaran organisasi dengan cara efektif dan efisien melalui perencanaan, pengorganisasian dan pengendalian sumber daya organisasi.

Suatu perusahaan dalam melaksanakan kegiatannya, baik perusahaan yang bergerak dibidang manufaktur, perdagangan maupun jasa akan berusaha untuk mencapai tujuan yang telah ditetapkan sebelumnya. Satu hal yang penting yaitu bahwa keberhasilan berbagai aktivitas didalam perusahaan dalam mencapai tujuan salah satunya adalah kenyamanan lingkungan kerja. Kenyamanan lingkungan kerja karyawan dapat memicu karyawan untuk bekerja lebih baik sehingga kinerja karyawan dapat dicapai secara maksimal.

Lingkungan kerja yang baik diharapkan dapat memacu kinerja karyawan yang tinggi. Perusahaan harus dapat memperhatikan kondisi yang ada dalam perusahaan baik didalam maupun diluar ruangan tempat kerja, sehingga karyawan dapat bekerja dengan lancar dan merasa aman. Dengan terciptanya lingkungan kerja yang nyaman dan menyenangkan, maka tentunya akan membentuk budaya kerja yang cukup produktif sehingga setiap anggota tim selalu memberikan performa terbaiknya untuk menyelesaikan tugas-tugasnya sesuai dengan peran mereka.

Titik tolak dari pada lingkungan kerja ini adalah tingginya produktifitas perusahaan. Dengan demikian perbaikan lingkungan kerja ini sama sekali bukan untuk tujuan mewah atau pengadaan fasilitas-fasilitas untuk kemewahan karyawan. Oleh karena itu tujuan utamanya adalah menaiknya kinerja, maka dalam perencanaan perbaikan lingkungan kerja ini, pengadaan fasilitas-fasilitas untuk karyawan adalah sekedar untuk mendorong kenaikan kinerja tersebut. Seiring dengan cepatnya perubahan lingkungan eksternal, teknologi informasi dan komunikasi saat ini maka dalam upaya menciptakan lingkungan yang baik, peran pimpinan sangatlah penting terutama dalam memilih struktur organisasi dan gaya manajemen yang akan diterapkan. Pemilihan ini harus benar-benar melalui analisis lingkungan yang sangat cermat. Perlu dipilih gaya manajemen yang sesuai dengan situasi dan kondisi lingkungan kerja. Tujuannya adalah untuk mewujudkan perusahaan dengan kinerja tinggi.

Menurut Mangkunegara (2017), Kinerja merupakan hasil kerja secara kuantitas dan kualitas yang dicapai oleh seorang karyawan dalam melaksanakan tugasnya sesuai dengan tanggung jawab yang diberikan kepadanya.

Kinerja perusahaan merupakan faktor yang sangat penting dalam meningkatkan daya saing perusahaan. Hanya perusahaan yang memiliki daya saing tinggi yang akan tetap eksis dalam era kompetitif ini. Perusahaan harus dapat mengelola semua potensi yang ada baik itu internal maupun eksternal. Perusahaan dengan kinerja yang tinggi akan terwujud apabila 
didukung oleh seluruh tingkatan sumber daya manusia dalam perusahaan yang terdiri mulai dari direktur, manajer, sampai dengan para staff lainnya yang berkinerja tinggi. Tetapi banyak hal yang mempengaruhi kinerja karyawan diperusahaan, antara lain: lingkungan kerja yang kondusif, pengetahuan, penggunaan alat, sikap, perbaikan dan lingkungan kerja, tanggung jawab, motivasi kerja, kemampuan dan keterampilan

PT. Inti Boga Lestari adalah perusahaan yang bergerak di bidang penyediaan roti dan kue. Dalam perkembangan bisnisnya, perusahaan menciptakan inovasi baru, produk-produk baru yang beragam. Selain itu setiap tahun selalu membuat outlet baru dengan konsep baru pula. Sejalan dengan dibukanya outlet baru market juga berkembang melalui kerjasama dengan restoran-restoran siap saji. Perusahaan juga telah menjalin kerjasama dengan restoran siap saji terutama di Jakarta Selatan untuk mensupply kue ulang tahun yang diadakan di seluruh outlet Jakarta Selatan, Bogor, Depok, Tangerang, Bekasi (jabodetabek).

Dalam kurun waktu 2017-2019 perusahaan cenderung mengalami penurunan pemesanan atau penjualan, banyak target yang dicanagkan tidak mampu terealisasi dengan baik. Kondisi ini penulis sinyalir akibat dari lingkungan kerja yang kurang nyaman, suhu udara panas tidak banyak fasilitas pendingin dan sarana lainnya yang kurang memadahi. Lingkungan kerja yang tidak baik ataupun situasi yang ada disekitar seperti kondisi yang disampaikan tersebut mejadikan karyawan kurang fokus dalam mengerjakan tugas yang diberikan.

Berdasarkan paparan diatas, maka penulis terrtarik untuk melaksanakan penelitian dengan judul "Pengaruh Lingkungan Kerja Terhadap Kinerja Karyawan Pada PT. Inti Boga Lestari di Jakarta Selatan)".

\section{B. Rumusan Masalah}

1. Bagaimana lingkungan kerja pada PT. Inti Boga Lestari di Jakarta Selatan?.

2. Bagaimana kinerja karyawan pada PT. Inti Boga Lestari di Jakarta Selatan?.

3. Adakah pengaruh antara lingkungan kerja terhadap kinerja karyawan pada PT. Inti Boga Lestari di Jakarta Selatan?.

\section{Tujuan Penelitian}

1. Untuk mengetahui kondisi lingkungan kerja pada PT. Inti Boga Lestari di Jakarta Selatan.

2. Untuk mengetahui kondisi kinerja karyawan pada PT. Inti Boga Lestari di Jakarta Selatan.

3. Untuk mengetahui pengaruh antara lingkungan kerja terhadap kinerja karyawan pada PT. Inti Boga Lestari di Jakarta Selatan.

\section{TINJAUAN PUSTAKA}

\section{Lingkungan Kerja}

Lingkungan kerja adalah keseluruhan alat perkakas dan bahan yang dihadapi, lingkungan sekitarnya dimana seseorang bekerja, metode kerjanya serta pengaturan kerjanya baik sebagai perseorangan maupun kelompok. Sedarmayanti (2016).

\section{Kinerja Karyawan}

Menurut Mangkunegara (2019) pengertian kinerja adalah hasil kerja secara kualitas dan kuantitas yang dicapai oleh seorang pegawai dalam melaksanakan tugasnya sesuai dengan tanggung jawab yang diberikan kepadanya.

\section{METODE PENELITIAN}




\section{Populasi}

Populasi dalam penelitian ini berjumlah 58 responden PT. Inti Boga Lestari di Jakarta Selatan

\section{Sampel}

Teknik pengambilan sampling dalam penelitian ini adalah sampel jenuh, dimana semua anggota populasi dijadikan sebagai sampel. Dengan demikian sampel dalam penelitian ini sampel yang digunakan berjumlah 58 responden.

\section{Jenis Penelitian}

Jenis penelitian yang dipakai adalah asosiatif, dimana tujuannya adalah untuk mengetahui atau mencari keterhubungan antara variabel independen terhadap variabel dependennya

\section{Metode Analisis Data}

Dalam menganalisis data digunakan uji validitas, uji reliabilitas, analisis regresi linier sederhana, analisis koefisien korelasi, analisis koefisien determinasi dan pengujian hipotesis.

\section{HASIL PENELITIAN}

\section{Analisis Deskriptif}

Pada pengujian ini digunakan untuk mengetahui skor minimum dan maksimum skor tertinggi, ratting score dan standar deviasi dari masing-masing variabel. Adapun hasilnya sebagai berikut:

Tabel 1. Hasil Analisis Descriptive Statistics

\section{Descriptive Statistics}

\begin{tabular}{|l|r|r|r|r|r} 
& N & \multicolumn{1}{|c|}{ Minimum } & Maximum & Mean & \multicolumn{1}{c}{ Std. Deviation } \\
\hline Lingkungan kerja (X) & 58 & 30 & 49 & 37.67 & 4.628 \\
\hline Kinerja Karyawan (Y) & 58 & 29 & 48 & 37.90 & 4.208 \\
\hline Valid N (listwise) & 58 & & & & \\
\hline
\end{tabular}

Lingkungan kerja diperoleh varians minimum sebesar 30 dan varians maximum 49 dengan ratting score sebesar 37,67 dengan standar deviasi 4,628. Skor ini termasuk pada rentang sakala 3,40 - 4,19 dengan kriteria baik atau setuju.

Kinerja karyawan diperoleh varians minimum sebesar 29 dan varians maximum 48 dengan ratting score sebesar 37,90 dengan standar deviasi 4,208. Skor ini termasuk pada rentang sakala 3,40-4,19 dengan kriteria baik atau setuju.

\section{Analisis Verifikatif.}

Pada analisis ini dimaksudkan untuk mengetahui pengaruh variabel independen terhadap variabel dependen. Adapun hasil pengujian sebagai berikut:

\section{a. Analisis Regresi Linier Sederhana}

Uji regresi ini dimaksudkan untuk mengetahui perubahan variabel dependen jika variabel independen mengalami perubahan. Adapun hasil pengujiannya sebagai berikut:

Tabel 2. Hasil Pengujian Regresi Linier Sederhana

\begin{tabular}{lr|r|r|r|r} 
& \multicolumn{2}{c}{ Coefficients $^{\mathbf{a}}$} \\
& \multicolumn{2}{c}{$\begin{array}{l}\text { Unstandardized } \\
\text { Coefficients }\end{array}$} & $\begin{array}{c}\text { Standardized } \\
\text { Coefficients }\end{array}$ & & \\
Model & \multicolumn{1}{c}{ B } & Std. Error & Beta & t & Sig. \\
\hline 1 (Constant) & 10.647 & 2.794 & & 3.810 & .000 \\
\hline Lingkungan kerja $(\mathrm{X})$ & .723 & .074 & .795 & 9.824 & .000 \\
\hline
\end{tabular}


Berdasarkan hasil pengujian pada tabel di atas, diperoleh persamaan regresi $\mathrm{Y}=$ $10,647+0,723 X$. Dari persamaan tersebut dijelaskan sebagai berikut:

1) Konstanta sebesar 10,647 diartikan jika lingkungan kerja tidak ada, maka telah terdapat nilai kinerja karyawan sebesar 10,647 point.

2) Koefisien regresi lingkungan kerja sebesar 0,723 , angka ini positif artinya setiap ada peningkatan lingkungan kerja sebesar 0,723 point maka kinerja karyawan juga akan mengalami peningkatan sebesar 0,723 point.

\section{b. Analisis Koefisien Korelasi}

Analisis koefisien korelasi dimaksudkan untuk mengetahui tingkat kekuatan hubungan dari variabel independen terhadap variabel dependen. Adapun hasil pengujian sebagai berikut:

Tabel 3. Hasil Pengujian Koefisien Korelasi Lingkungan kerja Terhadap Kinerja Karyawan.

\begin{tabular}{|c|c|c|c|}
\hline \multirow{2}{*}{\multicolumn{2}{|c|}{ Correlations $^{b}$}} & & \\
\hline & & $\begin{array}{l}\text { Lingkungan } \\
\text { kerja }(X)\end{array}$ & $\begin{array}{c}\text { Kinerja Karyawan } \\
(\mathrm{Y})\end{array}$ \\
\hline \multirow[t]{2}{*}{ Lingkungan kerja $(\mathrm{X})$} & Pearson Correlation & 1 & $.795^{* *}$ \\
\hline & Sig. (2-tailed) & & .000 \\
\hline \multirow[t]{2}{*}{ Kinerja Karyawan (Y) } & Pearson Correlation & $.795^{\star *}$ & 1 \\
\hline & Sig. (2-tailed) & .000 & \\
\hline
\end{tabular}

\section{c. Analisis Koefisien Determinasi}

Analisis koefisien determinasi dimaksudkan untuk mengetahui besarnya persentase pengaruh dari variabel independen terhadap variabel dependen. Adapun hasil pengujian sebagai berikut:

Tabel 4. Hasil Pengujian Koefisien Determinasi Lingkungan kerja Terhadap Kinerja Karyawan.

\begin{tabular}{|c|c|c|c|c|}
\hline \multicolumn{5}{|c|}{ Model Summary } \\
\hline Model & $\mathrm{R}$ & R Square & $\begin{array}{l}\text { Adjusted R } \\
\text { Square }\end{array}$ & $\begin{array}{c}\text { Std. Error of the } \\
\text { Estimate }\end{array}$ \\
\hline 1 & $.795^{\mathrm{a}}$ & .633 & .626 & 2.573 \\
\hline
\end{tabular}

Berdasarkan hasil pengujian diperoleh nilai determinasi sebesar 0,633 artinya lingkungan kerja memiliki kontribusi pengaruh sebesar $63,3 \%$ terhadap kinerja karyawan, sedangkan sisanya sebesar $36,7 \%$ dipengaruhi oleh faktor lain yang tidak dilakukan penelitian.

\section{d. Uji Hipotesis}

Pengujian hipotesis dengan uji $\mathrm{t}$ digunakan untuk mengetahui hipotesis mana yang diterima.

Rumusan hipotesis: Terdapat pengaruh yang signifikan antara lingkungan kerja terhadap kinerja karyawan.

Tabel 5. Hasil Uji Hipotesis Lingkungan kerja Terhadap Kinerja Karyawan. 


\begin{tabular}{|c|c|c|c|c|c|c|}
\hline \multicolumn{7}{|c|}{ Coefficients $^{a}$} \\
\hline \multirow{2}{*}{\multicolumn{2}{|c|}{ Model }} & \multicolumn{2}{|c|}{$\begin{array}{l}\text { Unstandardized } \\
\text { Coefficients }\end{array}$} & \multirow{2}{*}{$\begin{array}{c}\text { Standardized } \\
\text { Coefficients } \\
\text { Beta }\end{array}$} & \multirow[b]{2}{*}{$\mathrm{t}$} & \multirow[b]{2}{*}{ Sig. } \\
\hline & & $\mathrm{B}$ & Std. Error & & & \\
\hline & (Constant) & 10.647 & 2.794 & & 3.810 & .000 \\
\hline & Lingkungan kerja (X) & .723 & .074 & .795 & 9.824 & .000 \\
\hline
\end{tabular}

a. Dependent Variable: Kinerja Karyawan (Y)

Berdasarkan hasil pengujian pada tabel di atas, diperoleh nilai $\mathrm{t}$ hitung $>\mathrm{t}$ tabel atau $(9,824>2,003)$, dengan demikian hipotesis yang diajukan bahwa terdapat pengaruh yang signifikan atara lingkungan kerja terhadap kinerja karyawan diterima.

\section{Pembahasan Hasil Penelitian}

\section{Kondisi Jawaban Responden Variabel Lingkungan kerja}

Berdasarkan jawaban responden, variabel lingkungan kerja diperoleh ratting score sebesar 37,67 berada di rentang skala 3,40 - 4,19 dengan kriteria baik atau setuju.

\section{Kondisi Jawaban Responden Variabel Kinerja Karyawan}

Berdasarkan jawaban responden, variabel kinerja karyawan diperoleh ratting score sebesar 37,90 berada di rentang skala 3,40 - 4,19 dengan kriteria baik atau setuju.

\section{Pengaruh Lingkungan kerja Terhadap Kinerja Karyawan}

Lingkungan kerja berpengaruh signifikan terhadap kinerja karyawan dengan persamaan regresi $\mathrm{Y}=10,647+0,723 \mathrm{X}$, nilai korelasi sebesar 0,795 atau memiliki hubungan yang kuat dengan kontribusi pengaruh sebesar 63,3\%. Pengujian hipotesis diperoleh nilai thitung $>t$ tabel atau $(9,824>2,003)$. Dengan demikian hipotesis yang diajukan bahwa terdapat berpengaruh signifikan antara lingkungan kerja terhadap kinerja karyawan diterima.

\section{KESIMPULAN DAN SARAN}

1. Kesimpulan

a. Variabel lingkungan kerja diperoleh ratting score sebesar 37,67 berada di rentang skala 3,40 - 4,19 dengan kriteria baik atau setuju.

b. Variabel kinerja karyawan diperoleh ratting score sebesar 37,90 berada di rentang skala 3,40 - 4,19 dengan kriteria baik atau setuju.

c. Lingkungan kerja berpengaruh signifikan terhadap kinerja karyawan dengan persamaan regresi $\mathrm{Y}=10,647+0,723 \mathrm{X}$, nilai korelasi sebesar 0,795 atau kuat dan kontribusi pengaruh sebesar $63,3 \%$ sedangkan sisanya sebesar $36,7 \%$ dipengaruhi faktor lain. Uji hipotesis diperoleh nilai $t$ hitung $>t$ tabel atau $(9,824>2,003)$.

\section{Saran}

a. Perusahaan harus menjamin bahwa lingkungan kerja mampu memberikan kenyamanan karyawan dalam melakukan pekerjaannya.

b. Perusahaan harus selalu memberikan semangat dan apresiasi yang layak untuk memastikan karyawan memiliki semangat kerja yang tinggi sehinga mampu mencapai tujuan yang diharapkan.

\section{DAFTAR PUSTAKA}

Abdullah, M (2014) Manajemen dan Evaluasi Kinerja Karyawan, Yogyakarta: Penerbit Aswaja Pressindo. 
Bangun, Wilson. 2012. "Manajemen Sumber Daya Manusia”. Jakarta Selatan: Erlangga Dessler, G. (2006.) Manajemen Sumber Daya Manusia (Jilid II). Jakarta Selatan: Indeks. Edi Sutrisno (2016). Manajemen Sumber Daya Manusia. Jakarta Selatan: Prenadamedia Group.

Gerry Dessler (2016) Human Resources Management, Prenticehall, London: International Inc. Handoko (2016) Manajemen Personalia dan Sumberdaya Manusia. Yogyakarta: BPFE.

Hasibuan, Malayu S.P. (2016). Manajemen Sumber Daya Manusia. Edisi Revisi. Jakarta Selatan: PT Bumi Aksara.

Imam Ghozali (2017). “Aplikasi Analisis Multivariate Dengan Program SPSS”. Edisi Kelima. Semarang: Badan Penerbit Undip.

Mangkunegara, Prabu Anwar. (2016). Evaluasi Kinerja SDM. Cetakan ke tujuh, PT Refika Aditama: Bandung.

Robbins, P.S, \& Judge, A.T. (2003). Organizational Behavior. Jakarta Selatan: Salemba Empat.

Sedarmayanti (2016) Manajemen Sumber Daya Manusia, Reformasi Birokrasi dan Manajemen Karyawan Negeri Sipil, Cetakan Kelima, Bandung: PT Refika Aditama.

Sudjana (2014) "Metode Statistika”, Bandung: Tarsido.

Sugiyono (2017), "Metode Penelitian Administrasi : dilengkapi dengan Metode $R \& D$ ”. Bandung: Alfabeta.

Suhartanto (2014). “Metode Riset Pemasaran”. Bandung: Alfabeta

Veithzal Rivai (2015) Manajemen Sumber Daya Manusia Untuk Perusahaan, Jakarta Selatan: Raja Grafindo Persada.

Wibowo (2015) Manajemen Kinerja, Jakarta Selatan: PT. Raja Grafindo Persada.

Winata, H. (2019). Hubungan Motivasi Terhadap Kinerja Karyawan Pada Bank Pembangunan Daerah Jawa Barat Dan Banten Tbk.(Bank Bjb) Cabang Bsd-Tangerang Selatan. JENIUS (Jurnal Ilmiah Manajemen Sumber Daya Manusia), 2(2), 212-223.

Yuangga, K. D., \& Sunarsi, D. (2018). The Influence of Procrastination and Low Time Management on Student Self Efficacy (at MA Soebono Mantofani). PINISI Discretion Review, 2(1), 85-92. 